\title{
The Revival of Rhetoric, the New Rhetoric, and the Rhetorical Turn: Some Distinctions
}

\author{
DILIP PARAMESHWAR GAONKAR University of Illinois
}

Key Words: Rhetoric; rhetorical turn; new rhetoric; revival of rhetoric; rhetoric of inquiry; constitutive rhetoric; figural language; ideology.

\begin{abstract}
Each of the three phrases - the revival of rhetoric, the new rhetoric, and the rhetorical turn-points to a rediscovery of rhetoric in contemporary thought. However, the scholarly work, motivation and commitments associated with each phrase invokes and puts into play a different notion of rhetoric. In this paper, I explore those differences with a view to showing how the "rhetorical tum, " unlike the "revival of rhetoric" and the "new rhetoric," repositions rhetoric as a "metadiscipline." Thus, it signifies a radical shift in the self-understanding of rhetoric.
\end{abstract}

\section{The Revival of Rhetoric}

Although the idea of a "rhetorical turn" is of recent vintage, there has been intermittent talk about a "revival of rhetoric" since the beginning of this century. Such an anticipation of a revived rhetoric became an institutional and disciplinary reality in the first quarter of this century with the establishment of separate departments of Speech (later known as "Speech Communication") in some of the leading American universities. ${ }^{l}$ Although these departments were initially driven by the pedagogical ideals of imparting effective communicative skills, especially those of public speaking, debate and argumentation, in response to the growing specialization and professionalization of higher education, they gradually turned to a scholarly study of rhetoric in its theoretical, historical and critical dimensions. In due course, some of these departments were authorized to grant doctoral degrees.

As the American teachers of public speaking set out to revive rhetoric, there already existed considerable literature on the study of rhetoric. It consisted of two distinct types. First, there was abundant pedagogical material on the art of public speaking and on other forms and techniques of effective communication. This pedagogical literature is part of what George Kennedy calls the tradition of "technical rhetoric" whose roots can be traced with remarkable continuity all the way back to the handbook tradition of the ancients. This pedagogical and technical tradition, always susceptible to the changes in climate of opinion, has been periodically renovated, and sometimes mutilated, in response to the dominant intellectual and cultural influences of the time. But on the whole, this tradition has survived intact with an identifiable core of discursive precepts and practices since the demand for practical training in communicative skills has remained relatively constant throughout the Western cultural history.

The second type of literature dealt with the history of thetoric. There was no separate study of rhetorical theory as such. The theoretical understanding of rhetoric was equated with a mastery of the history of rhetoric, or to be more precise, a mastery of key texts within the rhetorical tradition. Hence, the traditional method of historical/theoretical studies in rhetoric may be characterized as that of the history of ideas. Two books by Charles Sears Baldwin, a professor of Rhetoric at the Columbia University-Ancient Rhetoric 
and Poetic (1924) and Medieval Rhetoric and Poetic (1928), both bearing the subtitle "interpreted from representative works"-provided the model for this sort of historical/theoretical scholarship."

The students of rhetoric within the Speech Communication field continued to operate along these two lines of scholarly endeavor suggested by the existing literature. They added a new arena of inquiry which gradually came to dominate the research activity within the field - the study of public address. They undertook to examine public discourse, especially political oratory, in its historical and biographical context. Such concentration on a specific object of study in turn gave rise to a distinctive mode of critical practice called "rhetorical criticism." The evolution of the relationship between public address studies and rhetorical criticism is itself a complex subject which requires further study, ${ }^{3}$ But one thing is clear. It is by means of historical and critical study of public address more than any other subject that the American Speech Communication departments as a whole were able to place their distinctive stamp on the study of rhetoric. This is not to suggest that the Speech Communication scholars were the first to study oratory and other forms of public discourse. Nor am I claiming that they invented the genre of "rhetorical criticism." One can find the rudiments of a rhetorical criticism of oratory as early as Longinus's astute observations on Demosthenic style. Cicero's Brutus and De Optimo Genere Oratorum furnish additional evidence of a critical impulse that sought to examine oratorical discourse in terms of its suasory qualities. But within the ambit of modern academic scholarship, it was clearly the Speech Communication scholars who first attempted to treat oratorical discourse as an autonomous cultural artifact worthy of critical attention. While the historians and political philosophers were content to examine oratorical discourse as documentary evidence in reconstructing the ideological terrain of a given age, the Speech Communication scholars began to study it in terms of what was most distinctive about it, namely, its persuasive dimension (as constituting a relatively autonomous sphere of symbolic action). ${ }^{s}$ Moreover, this confluence of interests between an historically grounded study of public address and a theoretically motivated concern for rhetorical criticism paved the way towards establishing an indigenous scholarly tradition within the field, a sign of emerging maturity.

To be sure, during this period research in rhetoric was also being conducted by scholars in other fields, especially in classics, Renaissance studies, and the modern languages and literatures. Here the motivation was quite different. These scholars were not seeking to revive rhetoric and to establish it as an autonomous discipline. They were drawn to a study of rhetoric because it so happened that an understanding of rhetoric was indispensable in making sense of the texts and times they were examining. And through such studies they came to appreciate rhetoric as a ubiquitous cultural process that stretches across the whole of Western civilization. A great deal of first rate historical and textual (theoretical) scholarship in rhetoric thus originated in fields outside of Speech Communication and was unencumbered by disciplinary anxieties.

It is against this background of modern academic scholarship in rhetoric that one has to examine the idea of a "rhetorical turn." In the literature broadly identified above, one is unlikely to come across the claim regarding the centrality of rhetoric in contemporary thought, a key presupposition of the rhetorical turn. To find the precedents for such a claim one has to return to the classical texts. It is the sort of claim Plato ironically ascribes to the sophist Gorgias who, when asked by Socrates to specify the subject-matter of rhetoric, spiciously declares that it deals with "tho greatest of human concerns." and that it 
the greatest good because it insures "not only personal freedom for individuals, but also mastery over others in one's own country" (Gorgias, 451-452). Similarly, the youthful Cicero, in De Inventione, describes the orator as a culture-hero who by employing his powers of "reason and eloquence" (ratio and oratio) once taught men that "wandered at large in the fields like animals and lived on wild fare" to voluntarily give up their savage ways and to found political communities in which they could engage in "every useful and honorable occupation," and "submit to justice without violence" (I. ii. 2-3). Later in the Renaissance we find Lorenzo Valla fulminating against philosophy as he "revives Quintilian's claim that philosophers originally stole from oratory, and wishes that Cicero "would have attacked the thieving philosophers with the sword of eloquence-queen of all things-entrusted to him, and had punished the malefactors " ". ${ }^{6}$ But these were generally polemical and promotional claims (what Vickers calls laus eloquentiae), frequently found as commonplaces in the "accessus" section of the ancient rhetorical treatises, and obviously never meant to be argumentatively secured. ${ }^{7}$ However, in the modern era almost from the time of Descartes, especially in the academic scholarship of the 19 th and the 20th centuries after the Romantic upsurge against rhetoric, one rarely finds rhetoric given a pivotal place in cultural architecture. The genre of laus eloquentiae virtually disappears. Rhetoric is increasingly treated as an historical phenomenon rather than as a living force, despite its continuing cultural role in politics, literature, and education. Those who undertook to study rhetoric felt compelled to justify their present interest by reiterating its historical significance. Some scholars went so far as to justify a study of rhetoric in order to overcome it. "We are freed from rhetoric only by study of its history," wrote Pual Shorey in 1908. What is intriguing about this statement is not that a Platonist like Shorey said it, but rather that this telling phrase serves as the inaugural epigram fifty five years later to George Kennedy's The Art of Persuasion in Greece (1963), the first in a multivolume historical study of classical rhetoric and its abiding cultural influence. Kennedy, while manifestly sympathetic to his subject, nevertheless assumes, as it were unconsciously, a defensive posture by citing Shorey's dictum without comment or irony. ${ }^{8}$ It was unlikely that any scholar would have ventured to anoint rhetoric as the queen of cultural studies within such a climate of opinion.

\section{The New Rhetoric}

This defensive posture persists in the twentieth century academic scholarship on rhetoric. The Speech Communication scholars, the group most explicitly committed to a revival of rhetoric, were more concerned about the viability of rhetoric in the modern age than its alleged centrality. There was genuine anxiety about conceptual ossification - an uneasy perception that rhetoric had not progressed significantly beyond what the ancients had enunciated. There were periodic calls for a new, conceptually refurbished rhetoric better adapted to the exigencies of the modern age.

Thus, the idea of a "new rhetoric" came into vogue. The relevant writings of a group of scholars-I.A. Richards, Kenneth Burke, Richard McKeon, Richard Weaver, and Chaim Perelman and L. OlbrechtsTyteca-acquired canonical status as constituting the new rhetoric. Although none of these writers came from the speech communication discipline, their ideas came to dominate whatever theoretical speculation there was in the discipline. But their ideas, even in the popularized versions that were initially disseminated in the Speech Communication journals, did not cohere into a conceptual whole. Perelman and Olbrechts-Tyteca, the only ones with a programmatic statement to offer, wanted to 
reconstitute rhetoric along the lines of topical/nonformal reasoning by recuperating a tradition stretching from Aristotle to Whately. Kenneth Burke wanted to reconstitute the hidden history of rhetoric by reinterpreting the tradition of debunking stretching from Bentham to the three modern masters of suspicion, Marx, Nietzsche, and Freud. Whatever the merits of McKeon's ideas, the prose of this immensely erudite classical scholar was forbiddingly inaccessible. Only a few of his historical essays on rhetoric were to have an abiding influence. In the early 1970s, McKeon's essay on rhetoric as an "architectonic productive art" received considerable attention but its implications were never spelled out in sufficient detail. ${ }^{9}$ In his provocative little book, The Philosophy of Rhetoric, I. A. Richards reduced rhetoric to metaphor and thus repeated a gesture so characteristic of that historical pattern, noted by Genette and Todorov, marking the progressive shrinking of rhetoric from its five offices (inventio, dispositio, elocutio, memoria, and pronuntiatio) and three functions (docere, movere, and delectare) to just one office (elocutio) and to just one function (delectare). ${ }^{10}$ Of the five people whose names are invariably associated with the new rhetoric, Weaver was the least problematic. He was conceptually accessible and politically congenial (conservative), but his writings did not open up new vistas for rhetoric. His essays, written in an engaging style, celebrated the traditional values of humanistic culture, of which rhetoric is a constituent part, against the growing domination of a scientistic world view. But there was little that could be regarded as conceptually innovative; Weaver reiterated the Platonic subordination of rhetoric to dialectic in his famous essay, "The Phaedrus and the Nature of Rhetoric." II

What these five "new rhetoricians" had in common was a commitment to refocus contemporary attention on rhetoric in a world increasingly dominated by science and the scientific method. They were determined to challenge the modernist fact/value distinction which, they believed, had severely attenuated the possibility of the public use of reason in ethics and politics. In rhetoric, they found, not an alternative to reason but an enlarged version of it that could address and negotiate the vexing questions of public life. Writing as they did in the years surrounding the Great War, the new rhetoricians were searching for a cultural form and practice that would promote social cohesion without erasing differences between the contending forces within and among communities. Here, once again, they turned to rhetoric. To imagine and to promote rhetoric in this enlarged sense as a constitutive cultural praxis, as McKeon recognized, one had to be a pluralist both in politics and in philosophy. Apart from such broad affinities, the "new rhetoricians" did not share, nor did they generate, a common fund of ideas, principles, perspectives, and whatever else it takes to mobilize an intellectual movement (revivalist, or otherwise). ${ }^{12}$

The fact that the new rhetoric remained at best a scattered set of ideas and texts (and at times a mere slogan) can be partly explained in terms of its essentially reactive character. The new rhetoric, surprising as it may seem, entails a defensive rather than an aggressive stance. ${ }^{13}$ To begin with, the idea of a new rhetoric itself is not new. The first book recommending itself as a new rhetoric appeared sometime in the Middle Ages. Thereafter, there were many attempts to modernize rhetoric throughout its turbulent history. The general impetus for a new rhetoric was always the same, an anxious conviction that the prevailing rhetoric was outmoded both in terms of sorietal changes and intellectual developments. Hence, one can observe throughout its history an obsessive preoccupation with the decadence and seeming irrelevance of contemporary rhetoric and a feverish urge to modernize so as to catch up with the changing times. This is evident, for instance, in George Campbell's Philosophy 
of Rhetoric which was hailed by George Saintsbury as "the most important treatise on the New Rhetoric that the eighteenth century produced." 4 Upon reading Campbell's careful and laborious prose one could hardly think of it as an instance of a feverish urge to modernize; and yet, it is as clear an instance as any of the "reactive theorizing" so very characteristic of rhetoric. By reactive theorizing, I mean those instances where the impetus for conceptual innovation comes from intellectual development taking place outside of a discipline rather than originating from within, say, as a result of an internal crisis.

Aristotle's Rhetoric provides an excellent counter-example to "reactive theorizing." Aside from responding to the challenge issued by Plato in Phaedrus, and also, if we are to believe Cicero (De Oratore, 3.35 .141 ), unwilling to let the fate of rhetoric be decided by the then dominant school of Isocrates, Aristotle was impelled to compose his treatise out of a genuine dissatisfaction with the way rhetoric was taught by his predecessors and contemporaries:

\footnotetext{
Now, the framers of the current treatises on rhetoric have constructed but a small portion of that art. The modes of persuasion are the only true constituents of the art: everything else is merely accessory. These writers, however, say nothing about enthymemes, which are the substance of rhetorical persuasion, but deal mainly with non-essentials. The arousing of prejudice, pity, anger, and similar emotions has nothing to do with essential facts, but is merely a personal appeal to the man who is judging the case (Rhetoric, 1354a).
}

In Sophistic Refutations (183b-184a), he similarly complains against the sophistic practice of teaching set-speeches, i.e., having the pupil study and memorize a series of model speeches singled out by his teacher. This type of instruction in rhetoric, says Aristotle with disdain, resembles that of a cobbler who, when asked by an apprentice to teach the art of making shoes, offered him a collection of ready-made shoes. In short, what we have in Aristotle is a clear instance of conceptual innovation that springs from a crisis internal to rhetoric; and moreover, the proposed solution to that crisis does not emanate from an alien metaphysic but looks empirically to the natural grounds of persuasion. Ordinary people, according to Aristotle, learn "to defend themselves and to attack others" verbally "either at random or through practice and from acquired habit. Both ways being possible, the subject can plainly be handled systematically, for it is possible to inquire the reason why some speakers succeed through practice and others spontaneously; and every one will agree that such an inquiry is the function of an art" (Rhetoric, 1354a).

In stark contrast, George Campbell's attempt to construct a "new rhetoric" was precipitated not by any perceived internal deficiency in rhetoric but by a shift in the philosophical predilection of the day in favor of the new science of human nature. In fact, Campbell believed that the ancient theorists had "developed practical rhetoric to near perfection. "15 However, he felt that rhetoric as embodied in the received tradition lacked a sound philosophical grounding, especially in light of the new science of human nature. Since all arts and sciences were to flow out of principles of human nature, rhetoric if it aspired to the status of an art, must also conform. Accordingly, Campbell "holds that the science of human nature is the foundation of rhetoric as an art, and that rhetoric's leading terms and principles are really located in human nature and authorized by it; consequently, the discovery of rhetoric's basic principles requires the examination of human nature." 16 So thorough a grounding of rhetoric in the intellectual fashion of the day is not without cost. It severely attenuates the distinctive character of rhetoric. Lloyd Bitzer, a leading Campbell scholar and the modern editor of his treatise, notes that "Campbell's discussion of rhetoric often can hardly be distinguished from his 
discussions of human nature. ${ }^{17}$ According to Bitzer:

Two critical assumptions are apparent in
Campbell's project. First, he assumed that
a general theory of rhetoric (a universal
theory of communication) must receive its
fundamental principles and processes from
rhetoric's foundation science of human na-
ture... The second implication is that in no
sense is the rhetorical art itself, when care-
fully inspected, found to be the source of
some of its own fundamental principles.

Thus, having to conform to an alien epistemology, the "new rhetoric" is left with neither "specificity" nor "autonomy." Sometimes such conformity to an abstract doctrine (science) leads to practical absurdities, as Bitzer's discussion of Campbell's classification of four types of discourses in terms of four faculties of the mind makes clear. ${ }^{19}$ These are some of the pitfalls of "reactive theorizing" characteristic of the so-called "new rhetorics."

Looking at the career of rhetoric, a cultural historian of materialist persuasion would be sorely tempted to generalize that the anxieties stemming from the "cultural lag" so characteristic of ideological structures is nowhere more acutely evident than in the history of rhetoric. This historical anxiety that announces the essential conservatism of rhetoric has given rise to a persistent scholarly topos about the relationship between the old rhetoric and the new rhetoric which Helen North once described, by recourse to an old proverb, as "the old salt in a new bottle." Unlike philosophy, which periodically denounces its past (Descartes, Nietzsche, Heidegger, and Derrida to name a few) in a radical gesture of self-purification, rhetoric clings to its past even as it struggles adapt to the discontinuities of the present.

Here I do not want my position to be misconstrued to mean that rhetoric ought not to respond and adjust to external changes. In fact, one of the virtues of rhetoric is that it continually adapts itself to external changes in social formations. This is evident in St. Augustine's refiguration of rhetoric in the service of Christianity, or the way rhetoric responded to the coming of bureaucracy in the Middle Ages by mutating into ars dictaminis, the rhetorical art of letter writing, and later into ars notaria. Nor am I critical of rhetoric drawing conceptual material from other fields to refurbish itself. All disciplines to do this. It is one thing to borrow conceptual material from sister disciplines when appropriate, but it is quite another thing to be a perennial latecomer conceptually. This is a persistent historical pattern, repeated time and again, that informs attempts to construct "new rhetorics," a pattern of conceptual scavenging and subservience that cannot be wished away, but needs to be confronted. Such a confrontation does take place in the so-called rhetorical turn to which we now turn.

\section{Rhetoric as Metadiscipline}

In the second half of the twentieth century, the new rhetoric selectively began to shed its defensive posture, and thus the way was paved for the so-called rhetorical turn. ${ }^{20}$ This is evident in two key texts of contemporary rhetorical theory-Kenneth Burke's A Rhetoric of Motives (1950) and Chaim Perelman and Olbrechts-Tyteca's The New Rhetoric: a treatise on argumentation (1958; English tr.1969). Burke's project for reconstituting the hidden history of rhetoric is motivated by the territorial metaphor of recovery and reclamation. To recover the territory that once belonged to rhetoric but now was held under the regency of usurpers, naturally calls for an aggressive posture. In Perelman and Olbrechts-Tyteca's work, rhetoric is offered as an alternative theory of argumentation that can provide grounding for philosophy, jurisprudence, and the human sciences in the wake of that colossal failure of the logicist tradition in philosophy from Descartes to logical positivism. In this 
scenario, which has its counterpart in the literature on the rhetorical turn, rhetoric is resituated, in the words of Calvin Schrag, "at the end of philosophy. "21 In this curious adaptation of the Nietzschean and Heideggerian vision of the end of philosophy, one hears faintly the staggering steps of that ancient humanist discipline, rhetoric, coming out of an ill-deserved cultural obscurity to the rescue of the discourse of the human sciences which have been left stranded on the ruins of philosophy.

This is not the place to determine the extent to which either Burke or Perelman or any of the other new rhetoricians anticipated the coming of the "rhetorical turn." Unlike the new rhetoric that remained largely entangled within the disciplinary problematics of the old rhetoric, the idea of the rhetorical turn makes a clean break from the previous discipline-bound notions of rhetoric. It opens up new possibilities for thetoric, not entirely unimagined, but long dormant and never before systematically enunciated.

The idea of a rhetorical turn involves a metadisciplinary move. It calls for a series of transcendences that set rhetoric free from its traditional confinement within the three distinctive fields of activityeducation, politics, and literature. Rhetoric, however, does not abandon its three distinctive fields of engagement but rather refigures them.

First, as a pedagogical practice, rhetoric is no longer viewed as a merely technical discipline for imparting communicative skills. It is now seen as the medium par excellence for molding the human personality. The two ends of rhetorical pedagogy are the preparation of the citizen and the creation of community, and this ideal is reminiscent of the educational mission of the older sophists and their successors within the rhetorical tradition-Isocrates, Cicero, Quintilian, the Renaissance humanists, and Vico. A contemporary version of this pedagogical vision can be found in the writings of James Boyd
White, who has figured prominently in the making of the rhetorical turn. In the context of legal pedagogy, White argues that rhetoric is a "constitutive art" that not only molds individual personality but creates and sustains culture and community. He writes;

I think it (rhetoric) should be seen not as a failed science nor as an ignoble art of persuasion (as it often is) but as the central art by which culture and community are established, maintained, and transformed. This kind of rhetoric - I call it "constitutive rhetoric"-has justice as its ultimate subject, and of it I think law can be seen as a species." 22

In his elaboration of this theme in a series of essays White clearly assigns to rhetoric a metadisciplinary status in relation to the discourse of law.

Second, rhetoric is transformed from a discursive instrument of politics into that which is constitutive of political discourse itself. This transformation is mediated through a certain equation between rhetoric, politics, and ideology. The equation reads roughly as follows: 1) Political discourse insofar as it is "interest begotten" discourse is preeminently ideological, 2) Ideology as a relatively autonomous symbolic system (and not a mere epiphenomenal reflection of the political economy) is rhetorically constituted. A series of routine ideological operations, such as, the "naturalistic fallacy" (the representation of the historical as the natural), the disguising of particular interests under the general interest, the reifications of polysemous political terms (such as, "rule of law," "public interest," "equality," etc) into interest bearing eulogistic "god terms" or dislogistic "devil terms," are shown to have a decidedly rhetorical structure. ${ }^{23}$ In this line of reasoning the distinction between the "rhetorical" and the "ideological" is blurred as rhetorical considerations are brought to bear on the whole of what Marxists call the "ideological structures" of society. By the same logic, rhetorical analysis or criticism comes to be equated with ideological 
analysis and critique. If it is through the resources of rhetoric that the dominant ideological meanings are fixed and made plausible against the natural polysemy of language, then, one must resort to rhetorical analysis and criticism to unpack and debunk those meanings. Thus rhetoric as a critical practice is made to set its course on the road to suspicion and becomes the discipline par excellence of debunking and demystification. In this critical frame, one's interest in discovering how rhetoric structures ideologically motivated political discourses is determined almost exclusively by one's desire to unmask it. One attends to the "constitutive" rhetoric implicit in political discourses only to reveal their routine and quiet deceptions. In certain respects the literature on the rhetorical turn pulls in two different directions. On the one hand people like James Boyd White stress the constitutive function of rhetoric in molding individual character and in creating and sustaining political communities, while, on the other hand, people like John Nelson and Michael Shapiro resort to the rhetorical lexicon in order to deconstruct and debunk the constitutive myths and fictions that stand in the way of individual emancipation and the possibility of a genuine community. ${ }^{24}$

Third, as a stylistic system of tropes and figures, rhetoric is traditionally confined normatively, if not in actual practice, to what is called the "peculiar" or the "literary" language of imaginative discourse, especially of poetry. The use of figures and tropes in discourse addressed to the understanding (seeking knowledge) as opposed to discourse addressed to imagination (seeking pleasure) was regarded as illicit. In the anti-rhetorical philosophical tradition, John Locke best expresses this position in his Essay Concerning Human Understanding (1690):

But yet, if we would speak of Things as they are, we must allow that all the Art of Rhetorick, besides Order and Clearness, all the artificial and figurative application of
Words Eloquence hath invented, are for nothing else but to insinuate wrong Ideas, move the Passions, and thereby mislead the judgement; so indeed are perfect cheat. ${ }^{25}$

With the emergence of Romantic aesthetics, given its stress on genius and spontaneity, even the value of technical mastery of tropes and figures for effective use in literature was challenged. Thus, the schoolmaster's mania for elaborate classification of tropes and figures came to be viewed as artificial and labored. The condemnation of these classificatory systems has been so universal in the modern era, says Vickers, that even the friends of rhetoric are prone to denigrate it. ${ }^{26}$

At any rate, the proponents of the rhetorical turn have challenged this persistent denigration of rhetorical tropes and figures and classificatory minutiae that go with it. While scholars like Paul de Man have initiated a revaluation of the Romantic hostility towards rhetoric, the proponents of the rhetorical turn have devoted most of their energy to questioning the normative confinement of tropes and figures to the "peculiar" language of literature. To begin with, they deny that tropes and figures are artificial creations of the schoolmaster"s classificatory mania. They point out that tropes and figures are a common feature of "ordinary" language rather than the special feature of "literary" language. Illiterate peasants are as inventive with them as the most refined literati. ${ }^{27}$ Du Marsais, writing in 1730, declared that "nothing is more natural, ordinary and common than fig. ures: more figures of speech are used in town square on a market-day than in many days of academic discussion. "28 Du Marsais was by no means the first to recognize this connection between figures and everyday life. According to Brian Vickers, the idea that tropes and figures derive from life and are no more than a mode of systematizing natural eloquence "can be found in Aristotle, Quintilian, Longinus, Puttenham, Abraham Fraunce, Sidney, and no doubt others." ${ }^{29}$ Vickers himself, following 
a suggestion of Gerald Else, characterizes figures functionally as "modes of the expression of feeling in language." 30

The proponents of the rhetorical turn, while lacking Vickers' historical grasp of the tradition of elocutio, agree with his general thesis that tropes and figures derive from life and that they are discursively unavoidable. However, they are not content to view figures functionally as psychological channels for representing emotions and feelings in language. They place a greater stress on the cognitive function of tropes and figures, Donald N. McCloskey, for instance, claims that the discourse of economics is heavily metaphorical. ${ }^{31} \mathrm{He}$ notes that "models" representing economic behavior so central to economic theorizing are in fact metaphors. McCloskey sees metaphors everywhere-the supply and demand "curves," the production functions, the "invisible hand," game theory, etc - they all turn out to be metaphors of one sort or another. Moreover, according to McCloskey, when someone like Gary Becker (whom McCloskey calls the "Kipling" of economic empire) startles us by comparing children to "durable goods" or by calling human skills "human capital" he is being more than ornamentally metaphorical. In fact, what Becker is doing with metaphors in economics is precisely what Max Black says metaphors can do-they function as "a distinctive mode of achieving insight." McCloskey goes even further and suggests that the mathematical reasoning so frequently employed by economists to enhance the scientific status of their discipline is thoroughly metaphorical.

In an immensely complex work, Metahistory (1974), Hayden White does for historiography what McCloskey does for economics. ${ }^{32}$ By imaginatively synthesizing the ideas of Giambattista Vico and Kenneth Burke, White comes up with a quarternary tropological scheme (metaphor, metonymy, synecdoche, and irony) to account for the deep structure of historical writing in the 19 th century by both the great historians (Michelet, Ranke, Tocqueville, and Burckhardt) and the great philosophers of history (Hegel, Marx, Nietzsche, and Croce). White further complicates this formalist scheme of four "master tropes" by noting their concordances with Northrop Frye's four "modes of emplotment" (romance, comedy, tragedy, and satire), Stephen Pepper's four "modes of explanation by formal argument" (formist, organistic, mechanistic, and contextualist), and Karl Mannheim's four "modes of ideological implication" (anarchist, conservative, radical, and liberal). ${ }^{33}$ This is not the place, nor am I competent, to assess the virtues of this complex formalist combinatoire to account for those vast and varied narrative monuments the nineteenth century historians have left us. To explore that technical question the readers can turn to the substantial amount of critical literature White's controversial book has already generated. For the present purpose it is sufficient to note two things. First, it appears that White privileges tropes over the other elements in his combinatoire. As David Carroll notes:

For while neither the level of emplotment,
the level of formal argument, nor the level
of ideological implication is ultimately de-
termining for White, beneath these surface
levels lies a deeper, more profound level
which is not historically, philosophically,
or ideologically determined, but is ulti-
mately determining of them-the metahis-
torical level. White distrusts all claims made
in the name of the "truth" or the "real"; and
the metahistorical level supposedly avoids
such claims by being entirely concerned
with language, that is to say, form.

This preoccupation with linguistic form leads White to derive from the rhetorical tradition four master tropes that he believes "prefigure and thus determine the historical field". "In short," White writes, "it is my view that the dominant tropological mode and its attendant linguistic protocol comprise the irreducibly 'metahistorical' basis of every historical work." 35 
Second, at a later date (1978) in the introduction to a collection of his essays, White extends this sort of privileging of tropological analysis from historiography to the whole of the human sciences. $\mathrm{He}$ writes:

The essays in this collection deal one way or another with the tropical element in all discourse, whether of the realistic or the more imaginative kind. This element is, I believe, inexpungeable from discourse in the human sciences, however realistic they may aspire to be. Tropic is the shadow from which all realistic discourse tries to flee. This flight, however, is futile; for tropics is the process by which all discourse constitutes the objects which it pretends only to describe realistically and analyze objectively. ${ }^{36}$

This sweeping statement (which I am not about to explain or to justify) gives an indicatation of how the proponents of the rhetorical turn have reversed the status of tropes and figures; so far from being the "perfect cheat" that they were to Locke, they have become the "necessities of the human mind" that they were to Vico.

These are the threefold enlargements by means of which rhetoric becomes a metadiscipline. What is involved here, as Leff has rightly observed in a related context, is a metonymic reversal. Rhetoric is transformed from a local artifact (or phenomenon) contained within the fields of education, politics, and literature into a global process that in turn contains and constitutes them. ${ }^{37}$ In this way rhetoric sets out to play the role assigned to it by McKeon, "the architectonic productive art." Thus, the phrase "rhetorical turn" signifies something more than what is implied by the two previous phrases, the "revival of rhetoric" and the "new rhetoric." It signifies a radical shift in the self-understanding of rhetoric.

\section{Notes}

1 Karl R. Wallace (ed.), History of Speech Education in America: background studies (New York: Appleton-Century-Crofts, 1954).

2 Charles Sears Baldwin published three important books on the history of rhetoric and literary criticism: Ancient Rhetoric and Poetic: interpreted from representative works (New York: MacMillan, 1924); Medieval Rhetoric and Poetic: interpreted from representative works (New York: MacMillan, 1928); Renaissance Literary Theory and Practice; classicism in the rhetoric and poetic of Italy, France, and England, 1400-1600 (NY: Columbia University Press, 1939). These three volumes were reissued by Peter Smith (Gloucester, MA) in 1959.

3 For an overview of the evolution of rhetorical criticism in the Speech Communication discipline, see Charles J. Stewart, "Historical Survey: Rhetorical Criticism in Twentieth Century America," in Explorations in Rhetorical Criticism ed. G.P. Mohrmann, Charles J. Stewart, and Donovan Ochs (University Park, PA: Pennsylvania State University Press,
1973). For a critical perspective on the relationship between rhetorical criticism and public address, see Stephen E. Lucas, "The Renaissance of American Public Address: Text and Context in Rhetorical Criticism," Quarterly Journal of Speech 74 (1988), 241-260.

4 Longinus, On the Sublime tr. W. Hamilton Fyfe (Cambridge, MA: Harvard University Press (Loeb Library), 1927).

5 For a sustained use of oratorical texts in constructing history, see, Richard Hofstadter, The American Political Tradition (New York: Vintage, 1948).

6 Brian Vickers, "Territorial Disputes: Philosophy versus Rhetoric," in Rhetoric Revalued ed. Brian Vickers (Binghamton, NY: Medieval and Renaissance Texts and Studies, 1982), 260.

7 Brian Vickers, In Defense of Rhetoric (Oxford: Clarendon Press, 1988), 11.

8 George A. Kennedy, The Art of Persuasion in Greece (Princeton: Princeton University Press, 1963), 2. The epigram from Shorey is from his 
essay-."Physis, Melete, Episteme," Transactions of American Philological Association 40 (1908), 185.

9 Richard McKeon, "The Uses of Rhetoric in a Technological Age: Architectonic Productive Arts," in The Prospect of Rhetoric eds. Lloyd F. Bitzer and Edwin Black (Englewood Cliffs, NJ: Prentice-Hall, 1971), 44-63.

10 I. A. Richards, The Philosophy of Rhetoric (New York: Oxford University Press, 1936).

11 Richard Weaver, The Ethics of Rhetoric (Chicago: Henry Regnery, 1953), 3-26.

12 For an excellent but brief account of new rhetoric, see, Thomas M. Conley, Rhetoric in the European Tradition (New York: Longman, 1990), 260-310.

13 Here one has to be careful to distinguish between the achievement of new "new rhetoricians" and the manner in which their work came to be integrated into the disciplinary matrix of speech communication. My characterization of the "new rhetoric" as "reactive" refers primarily to the early reception of their work within speech communication. The contributions of Burke, McKeon, and Perelman to the making of contemporary rhetorical theory is enormous. Each of them came to recognize the importance of rhetoric through a different route and deployed it to resolve different sets of problems: the early Burke to critique the aesthetic ideology of "art for art's sake"; McKeon to overcome the limitations of a purely dialectical approach to the study of "historical semantics" (the history of ideas and methods); and, Perelman to articulate a mode of reasoning about justice that went beyond legal formalism. There is nothing arbitrary or idiosyncratic about the place of rhetoric in their respective corpora. But the manner in which their work was initially appropriated in speech communication failed to grasp the complex intellectual itinerary that had led them to rediscover rhetoric. This is particularly evident in the early reception of Burke. The new rhetoric was seen simply as a generalized humanist alternative to the hegemonic discourse of "formalism," "positivism," and "scientism." Only recently, scholars such as Conley have noticed an emergent "Ciceronianism" in the work of some of the "new rhetoricians." If "new Ciceronianism" is a decisive feature of the new rhetoric (Conley makes a convincing case for it), that feature eluded those early speech communication scholars who read it largely as an extension of Aristotelian rhetoric.

14 A History of Criticism and Literary Taste in Europe, 3 vols. (New York: Dodd Mead, and Co., 1905), 2:470; cited by Lloyd Bitzer, "Editor"s Introduction," in George Campbell, The Philosophy of Rhetoric (Carbondale, IL: Southern Illinois University Press, 1988, 1963), vii.

15 The Philosophy of Rhetoric, Ixxv.

16 Bitzer, xix.

17 Bitzer, xix.

18 Bitzer, Xxv.

19 Bitzer, xx-xxi.

20 The literature on this topic has grown rapidly in recent years: George L. Dillon, Contending Rhetorics (Bloomington, IN: Indiana University Press, 1991); John S. Nelson, Allan Megill, and Donald McCloskey, eds. The Rhetoric of the Human Sciences: language and argument in scholarship and public affairs (Madison, WI: University of Wisconsin Press, 1987); R.H. Roberts and J.M.M. Good, eds., The Rediscovery of Rhetoric: persuasive discourse and disciplinarity in the human sciences (Charlottesville, VA: University of Virginia Press, 1993); Herbert W., Simons ed. Rhetoric in the Human Sciences (Newbury Park, CA: Sage Publications, 1989); Herbert W. Simons, ed. The Rhetorical Turn: invention and persuasion in the conduct of inquiry (Chicago: University of Chicago Press, 1990).

21 Calvin O. Schrag, "Rhetoric Resituated at the End of Philosophy," Quarterly Joumal of Speech 71 (1985), 164-174.

22 James Boyd White, Heracles' Bow: essays on the rhetoric and poetics of the law (Madison, WI: University of Wisconsin Press, 1985), 28. For other versions of constitutive rhetoric, see, Ronald Beiner, Political Judgment (Chicago: University of Chicago Press, 1983), 83-101; Maurice Charland, "Constitutive Rhetoric: The Case of the Peuple Quebecois" The Quarterly Journal of Speech 73 (1987), 133-150.

23 Michael Calvin McGee, "The 'Ideograph': A Link Between Rhetoric and Ideology," The Quarterly Journal of Speech 66 (1980), 1-16.

24 John S. Nelson, "Political Theory as Political Rhetoric" in What Should Political Theory Be 
Now? ed. John S. Nelson (Albany, NY: State University of New York Press, 1983), 169-240; Michael J. Shapiro, The Politics of Representation (Madison, WI: University of Wisconsin Press, 1988).

25 John Locke, An Essay Concerning Human Understanding ed. John W. Yolton, 2 vols. (New York: 1961), Book 3, Ch. 10, 105-106.

26 Vickers, In Defense of Rhetoric, 294.

27 Vickers, In Defense of Rhetoric, 299. To support his claim, Vickers cites Cicero, Orator, 24. 81 and Quintilian, Institutes of Oratory, 8.6 .75 .

28 Cited by Vickers, "Territorial Disputes," 257.

29 Vickers, "Territorial Disputes," 257.

30 Vickers, In Defense of Rhetoric, 296-297.

31 Donald N. McCloskey, "The Rhetoric of Economics," Journal of Economic Literature 31 (1983), 434-461; The Rhetoric of Economics (Madison, WI: University of Wisconsin Press, 1985), 54-86.
32 Hayden White, Metahistory: the historical imagination in nineteenth-century Europe (Baltimore: Johns Hopkins University Press, 1973).

33 White, Metahistory, 1-42.

34 David Carroll, "On Tropology: The Forms of History," Diacritics 6 (1976), 59-60.

35 White, Metahistory, xi.

36 White, Tropics of Discourse: essays in cultural criticism (Baltimore; The Johns Hopkins University Press, 1978), 1-2.

37 Michael Leff, "The Habitation of Rhetoric," in Argument and Critical Practices, Proceedings of the Fifth SCA/AFA Conference on Argumentation; ed. Joseph W. Wenzel (Annandale, VA: Speech Communication Association, 1987), 4.

DILIP PARAMESHWAR GAONKAR

DEPT. OF SPEECH COMMUNICATION

UNIVERSITY OF ILLINOIS

244 LINCOLN HALL

702 S. WRIGHT ST.

URBANA, ILLINOIS 61801

\section{Announcements}

\section{International Philosophical Preprint Exchange}

The International Philosophical Preprint Exchange is a new service on the Internet designed to foster improved communication among philosophers by providing a medium for the exchange of works in progress. All interested philosophers are invited to browse the Exchange's collection of working papers in all areas of philosophy, and to submit their own working papers. To receive instructions, send a piece of e-mail containing exactly the following four lines of text:

$$
\begin{aligned}
& \text { begin } \\
& \text { index } \\
& \text { send getting-started } \\
& \text { end }
\end{aligned}
$$

to the address "phil-preprints-service@ phil-preprints.1.chiba-u.ac.jp" (excluding quotes). A user's guide and a list of papers available will be returned to you by e-mail. 